\title{
COMMUNITY COLLEGES AND DISTANCE LEARNING
}

\author{
Kathleen Susan Ives
}

The Sloan Consortium

\begin{abstract}
The goal of community colleges is to serve local needs. Community colleges' low tuition helps keep higher education affordable for a diverse population. Distance learning holds the promise of providing yet another mechanism by which community colleges can bring education to a non-traditional student body. This paper explores the role of distance learning opportunities in community colleges within the context of today's current environmental scan.
\end{abstract}

\section{KEYWORDS}

Community Colleges, Access to Higher Education, Serving Non-Traditional College Students, Lifelong Learning

\section{INTRODUCTION}

Community colleges focus on providing higher education opportunities to both the community and the workforce. The United States boasts more than 1,844 community colleges. Of these, 1,101 are public institutions and 743 are private community colleges [1]. The philosophy that binds these institutions together includes open access and equity, comprehensive program offerings, a community-based philosophy, a commitment to teaching and to lifelong learning [2].

Yet, the nation's community colleges now face unprecedented challenges. In the past three years, student enrollment pressure has escalated, and college principals have struggled with new leadership paradigms, steep state budget cuts, limited facilities, faculty turnover and expenses, quality curriculum, a progressively more diverse student body, increasing numbers of students who need remedial work before they can take college-level classes, competition by for-profit institutions, and rising technology costs.

Seeking out innovative approaches to developing and growing distance learning programs may increase community colleges' capacity to address some of these issues without massive, new building projects and investments. In light of Sloan-C's goal relative to examining learning opportunities through Asynchronous Learning Networks (ALNs), this paper examines the community college today. The community college's development and growth is discussed to more appropriately place key trends in context. Major environmental factors are addressed, as well as challenges and opportunities for Sloan-C to support institutions servicing these nontraditional students in their quest for academic, vocational, and remedial education.

\section{HISTORY OF COMMUNITY COLLEGES}

Community colleges boast a rich history of providing courses mirroring the needs of the local community. More than 11 million students, about $44 \%$ of all undergraduate students, attend community 
colleges throughout the United States [2]. The average age of a typical community college student is 29 years old and s/he can expect to pay \$2,076 per year in tuition plus fees [2]. Reasons for attending a community college vary by student; however, the reasons often include low tuition, convenient location, class schedules, open admissions, and comprehensive course offerings.

Community colleges prepare students for the job market by offering entry-level career training programs, as well as courses for adult students who want to upgrade their skills for job re-entry or advancement. In addition, many community colleges allow high school students to take advanced placement classes, which count for credits toward their college degree. College students already enrolled at a four-year school often look to community colleges for courses not offered by their school.

Table 1 details the evolution of community colleges in the United States.

\begin{tabular}{|c|c|}
\hline 1901 & $\begin{array}{l}\text { Joliet Junior College (Illinois) is founded; the oldest existing public two-year } \\
\text { college. }\end{array}$ \\
\hline $1901-1929$ & Community colleges curriculum focuses on general liberal arts studies. \\
\hline 1931 & $\begin{array}{l}\text { The Junior College. This book by Walter Crosby Eells documented the growth and } \\
\text { curriculum of the public junior college, as well as its role in increasing access to } \\
\text { higher education. Eells' book is a very important text on the early development of } \\
\text { the public junior college. }\end{array}$ \\
\hline 1929-1939 & $\begin{array}{l}\text { During the Great Depression, community colleges offer job-training programs as a } \\
\text { means of minimizing widespread unemployment. }\end{array}$ \\
\hline Post 1945 & $\begin{array}{l}\text { After WW II, conversion of military industries to consumer goods creates an } \\
\text { economic transformation requiring new, skilled jobs. This trend, coupled with the GI } \\
\text { Bill giving thousands of working class men college scholarships for the first time in } \\
\text { U.S. history, creates the need for more higher education options. }\end{array}$ \\
\hline 1947 & $\begin{array}{l}\text { Publication of Higher Education for American Democracy by the President's } \\
\text { Commission on Higher Education. The commission report, popularly know as The } \\
\text { Truman Commission Report, called for, among other things, the establishment of a } \\
\text { network of public community colleges that would charge little or no tuition, serve as } \\
\text { cultural centers, be comprehensive in their program offerings with emphasis on civic } \\
\text { responsibilities, and would serve the area in which they were located. The } \\
\text { commission popularized the phrase community college, causing hundreds of existing } \\
\text { and new public two-year colleges to include community in their names. }\end{array}$ \\
\hline 1960s & $\begin{array}{l}\text { Community colleges become a national network with the opening of } 457 \text { public } \\
\text { community colleges; more than the total in existence prior to this decade. }\end{array}$ \\
\hline 1964-1979 & $\begin{array}{l}\text { Baby boomers come of age; fuel enrollment growth and facility growth, funded by a } \\
\text { robust economy and the social activism of the time. }\end{array}$ \\
\hline 1980 & $\begin{array}{l}\text { The federal Tribal Colleges Act establishes a community college on every Indian } \\
\text { reservation, which allows young people to go to college without leaving their } \\
\text { families. }\end{array}$ \\
\hline 1988 & $\begin{array}{l}\text { Commission on the Future of Community Colleges issues report "Building } \\
\text { Communities: A Vision for a New Century”. The report defined community not only } \\
\text { as a region to be served, but also as a climate to be created. Recommendations } \\
\text { include: community colleges should help build a sense of community by creating } \\
\text { partnerships and making facilities available to civic groups; community colleges } \\
\text { should become more active in providing remedial education: basic computation, }\end{array}$ \\
\hline
\end{tabular}




\begin{tabular}{|l|l|}
\hline & $\begin{array}{l}\text { composition, reading classes. These trends are the result of a society becoming } \\
\text { increasingly more fragmented. }\end{array}$ \\
\hline 2001 & Community colleges celebrate 100 years of service. \\
\hline
\end{tabular}

Table 1. History of Community Colleges

Source: Applied Research Center, 2005; Office of Vocational and Adult Education, 2001

\section{ENVIRONMENTAL SCAN}

The following includes general observations about the state of the community college in the Twenty-first Century.

\section{A. Leadership}

Between 1960 and 1975 community colleges growth and development required a corps of administrators with perspectives and skills different from skills required today. At that time, aggressive recruiting focused on the demand for administrative leaders who could cope with the difficulties associated with physical growth, broadened functions, and an increasingly heterogeneous student population at community colleges [3].

Beginning in the 1990s, the demand for two-year college leaders slowed as fewer higher education administrators were leaving their posts. Indeed, the qualifications sought by institutions today are of a different nature. The administrative skills needed to maintain and improve a community college system in an era fraught with continuous change, new forms of competition, and an increasingly diverse student population were not necessarily the same as those competencies required to establish the system [3].

Moreover, community colleges have traditionally accepted responsibility for workforce development; college leadership is now faced with many of the nation's jobs being outsourced overseas. Today's college leaders must not only be equipped to explore new opportunities providing the training necessary to support the small businesses and entrepreneurships that are replacing those jobs, but also be able to respond to the demands technological innovations are placing on the institution [4].

\section{B. Financing}

Far more than universities, community colleges' missions and goals rely on strong linkages to local financing. Community colleges depend on a mixed funding base. Some receive the bulk of their funding from local tax funds. Other institutions' primary funding comes in annual or bi-annual state level appropriations [5]. Every state community college system receives some level of state appropriation. While funding policies vary by state, community colleges are the segment of higher education most reliant on public funding. Nationally, the institutions receive an average of $60 \%$ of their revenue from state and local funds compared to an average of only 35\% at public four-year institutions [6].

When state finances are tight, higher education budgets are often cut disproportionately. To make matters worse, community colleges often absorb a disproportionate share of the higher education budget cuts. The decreasing availability of local support and a deep drop in state support has prompted community colleges to rely more on financing from student tuition and fees [5]. Whereas budget cuts at a university might effect a departmental change, cuts at a two-year college lead directly to cancelled classes, old technology, and ill-equipped laboratories. 


\section{Facilities}

Insufficient, unpredictable capital and operating funding, statewide governance issues and regulatory red tape have collided to create a structural deficit within community colleges, potentially threatening their mission of affordable and accessible education.

Many community colleges report poor facilities in major areas and space shortage for some programs [7]. Poor equipment, inadequate parking, lack of building security, lack of support for instruction (e.g. better support services, instructional media, and materials) are key issues.

\section{Faculty Turnover and Expenses}

High rates of faculty turnover can be costly to the reputation of an institution and to the quality of instruction. Community colleges can expect high rates of faculty turnover as an aging workforce retires. Other sources of attrition; however, can be attributed to organizational characteristics and the structural properties of faculty work. At some colleges, faculty and staff expenses have been eliminated through early retirement incentives or reductions in force.

The practice of employing part-time or adjunct faculty has steadily increased in community colleges as a way of offering classes at a lower cost. Hiring freezes and employee travel restrictions also have been a common reaction. Community colleges have been known to negotiate salary decreases with union representatives. In what translates to a de facto enrollment cap, many community colleges have frozen or reduced course sections and, in extreme cases, have eliminated whole programs and summer sessions [6].

\section{E. Quality}

Community colleges must learn from the quality movement in industry to become more responsive and customer-driven. Too many community college officials, like officials anywhere, have become entitled, privileged, tenured and secure at a time when the rest of the economy and society is scrambling for survival [8].

In education, a quality indicator is engagement. The Community College Survey of Student Engagement (CCSSE) was established in 2001 as part of the Community College Leadership Program at The University of Texas at Austin. CCSSE provides information about effective educational practice in community colleges and assists institutions in using that information to inform decision-making and formulate improvements in student learning and persistence. Student engagement, or the amount of time and energy that students invest in meaningful educational practices, is the underlying foundation of the effort [9].

\section{F. Diversity}

Community colleges must work to adapt to the increasing diversity of American society. For example, within the community college environment, varying geographic locations, demographics, governance structures, and institutional sizes create a multi-faceted array of institutions each with its own culture and unique population of students [10]. Also, the increase in the number of non-traditional students enrolled at community colleges adds to the heterogeneity of community college institutional cultures [10].

Community colleges enroll almost half of all U.S. undergraduates, serving disproportionately high numbers of at-risk first-generation, low-income, and adult students. As mentioned earlier, this highly 
diverse student population approaches community colleges with an impressive array of educational goals and aspirations, along with stunning variations in academic preparation and with daunting financial and personal challenges.

\section{G. Student Characteristics}

In a study conducted by Adleman [11], six distinct traditional-age populations are served by the community college:

1. A persistent group oriented toward traditional academic and occupational fields that establishes a path of attainment involving transfer and earning a bachelor's degree;

2. An equally persistent group oriented toward the intermediate occupational credentials awarded by community colleges that also establishes a path of attainment;

3. A group with significantly weaker secondary school preparation that struggles to acquire a modicum of credits in the community college, then stops;

4. A group that withdraws soon after entry to the community college, earning few if any credits;

5. Temporary visitors who are based in other types of institutions, principally four-year; and

6. A small population of undergraduate reverse transfers who evidence declining momentum toward credentials at any level.

Community colleges face the continued challenge of providing instruction and programming that satisfies the educational needs of such a diverse population.

\section{H. Competition by For-Profits}

For-profit schools are attracting students in record numbers and have become formidable competition for community colleges. The growth of for-profit colleges was nearly 30\% between 1996 and 2001, when national enrollment stood at 765,701 (the latest figure available) increasingly puts them in direct competition with public community colleges [12]. The public schools currently have national enrollment of 10.4 million students, $44 \%$ of all U.S. undergraduates [12]. In the past, the reputation of for-profit schools proved questionable within the academic community; however, today's for-profits, for example, turn out more students with associate's degrees in engineering-related technologies than public colleges do [13]. These institutions are also making inroads in other degrees such as business management and computer science [13]. Students feel they can graduate and enter the job market sooner because these institutions offer courses year-round. Additionally, for-profits have access to huge marketing and lobbying budgets, and tend to have newer, better-kept campuses and equipment [14].

\section{Technology}

Currently, rapid technological advancements have become the newest challenge impacting the agility of community colleges. Technology is expensive. A poor decision regarding software or hardware purchase means a college is left behind. As a college waits for technological innovations to stabilize and become more mainstream, the school risks losing students to other higher education providers.

Nonetheless, community colleges reportedly have the greatest number of enrollments in distance education courses, $48 \%$ as compared to $31 \%$ in four-year institutions [15]. Investments in digital technologies by community colleges continue to grow in the areas of online admissions, registration, student self-service options (course management, grade viewing, transcript ordering), technology skills, faculty development, campus technology support, and distance education via the Internet [16]. 


\section{DISTANCE EDUCATION AND THE COMMUNITY COLLEGE}

For the typical community college student, the idea that s/he could work full-time and study part-time becomes very appealing. Demands brought on by work, family, and life in general tend to preclude many students from taking courses sequentially in a face-to-face environment as dictated by the academic calendar. Distance learning also offers the opportunity to use technology, which serves as a prominent tool in today's workforce.

\section{A. Opportunities}

\section{Partnerships with Larger Institutions}

For financially-challenged community colleges, partnering with another institution in the development and hosting of a distance education program not only assists in the reduction of technological expenditures, but also enables the community college to take advantage of other skill sets such as instructional programming, multimedia expertise, and the like. For example, Quinsigamond Community College in Massachusetts has just finalized an agreement with UMass Online; whereby UMass Online will host and provide 24/7 customer support for Quinsigamond's distance education programming.

\section{Partnerships with High Schools and Businesses}

Community colleges can expand their reach by partnering with $\mathrm{K}-12$ systems, employers, and other community colleges. For example, Massachusetts Colleges Online (MCO) is a consortium of the 15 community colleges and 9 state colleges of Massachusetts. The institutions have joined to share their convenient and flexible online courses and programs with both high school and college students throughout the state and beyond [17]. Another example is Project SAIL (Specialty Asynchronous Industry Learning), a program in which community colleges collaborate to promote access, exchange, and dissemination of industry-driven programs for community college students. After completing an 18 month proof-of-concept pilot, the project has received funding for an additional two years from the Sloan Foundation to expand the project and help it become self-sustaining [18].

\section{Outsourcing Curriculum Development}

Building an inventory of distance learning curriculum quickly and cost effectively can prove daunting for many community colleges. Updating the curriculum can also be a formidable task. One-stop shops with no setup costs, no space or equipment commitments, and minimal implementation constraints provide a solution. For example, the eLearning Center [19] for colleges and universities contains content from major course developers, and is free of charge. The eLearning Center can be customized and branded for each school and utilized in partnership with local organizations, corporations, and community college partners.

\section{Enrollment Booster}

Many distance-learning initiatives have nothing to do with distance, but have everything to do with convenience. When course material is presented via a learning management system (LMS), students can read through the material, work on assignments, and email their instructors anytime. Students essentially 'schedule' the class themselves. The Massachusetts Department of Education is currently funding and piloting an Adult Basic Education (ABE) distance education project for a population interested in obtaining a general education diploma (GED), but who have time-and resource-challenges. 


\section{One Answer to Occupational Shortages}

Many community colleges are over-enrolled in programs such as nursing and dental hygiene; yet, significant occupational shortages exist in these and other industries [20]. Walden University, an accredited online university, has begun to explore potential partnerships with community colleges to produce qualified nurse educators, instructors, and training specialists. Walden has introduced an online degree program open to registered nurses with a diploma, an associate's degree, or a bachelor's degree, leading to a Master of Science degree in nursing with a specialization in education [20].

\section{Responding to the Needs of a Digital Generation}

An army sergeant based in Iraq, a woman whose parents have moved to another part of the country, another individual possessing a disability-these are the new populations that community college distance education programs can serve. Harrisburg Area Community College in Pennsylvania has launched a virtual campus as an extension of the institution's distance learning program [21]. Harrisburg's virtual campus provides workforce development programs and key support services such as advising, tutoring, registration, a bookstore, and a library. Students who participate in the virtual campus enroll for one of the following reasons: convenience, scheduling conflicts, not living in proximity of one of the college's four campuses, and/or are homebound.

\section{B. Challenges}

\section{Student Preparedness}

As mentioned earlier, today's community college student often requires a significant amount of remedial instruction. The online learning environment requiring discipline and some basic computer literacy may not prove appropriate for this type of learner [22].

\section{Student Retention}

The factors contributing to a community college student deciding to participate in an online course (work, family, life) often adversely affect retention. If a child becomes ill, or a job requires extra hours, the student may elect to drop out. Additionally, some students find the increased interaction between faculty and students was more than s/he expected, and feel daunted and unprepared for the workload [23].

\section{Faculty Resistance}

Since technology expenditures in community colleges tend to be less than in four-year institutions, there tends to be greater faculty resistance brought on by 'fear of the unknown'. Some faculty feel inhibited by the technology, fear online courses will take their students away, and feel the virtual environment promotes less interaction; these faculty members do not realize faculty/student interaction has the potential to increase via email and threaded discussions [22].

\section{Lack of Imaginative Programming}

Many distance education programs mirror correspondence courses and/or rote learning. Community colleges tend to follow that model by moving students through in a lackluster, computer-mediated environment [22]. This phenomenon occurs in part, because community colleges typically do not have the resources to develop an infrastructure that might include faculty training and mentoring, instructional design, and/or technology support. 


\section{FINAL THOUGHTS}

The market for distance education continues to grow [22, 24]. Lifelong learning is becoming a competitive necessity. Community colleges need to seek out new and innovative ways to create technology-supported, learner-centered experiences enhancing learning and satisfaction to compensate for the environmental forces impacting these institutions' growth and survival. The issues presented in this paper might be circumvented, or at least mitigated by institutional awareness and administrative commitment to remain current, informed, and prepared [25]. Sloan-C can contribute toward the fulfillment of this objective by working with community colleges to identify key trends, as well as by providing programs and tools assisting these institutions in the development and implementation of strategic plans that meet both foreseeable and unforeseeable challenges.

\section{ABOUT THE AUTHOR}

Kathleen S. Ives, D.M. has worked in online technology for over 20 years and serves as The Sloan Consortium's Events Producer. Formerly, Dr. Ives oversaw all forms of alternative instruction at Quinsigamond Community College in Worcester, MA (distance learning, accelerated programming). She teaches online for University of Phoenix and Axia College of Western University, and in an accelerated environment for working adults at both Regis College in Weston, MA and the University of Phoenix, Greater Boston Campus.

Dr. Ives began her career at CBS and helped to develop the service that evolved into Prodigy. She then spent fourteen years designing and implementing consumer online information services, first at AT\&T and then at Verizon where she spearheaded the development of the nation's first online Yellow Pages product, now called superpages.com. Dr. Ives sits on the Massachusetts Department of Education's Distance Learning Advisory Board for Adult Basic Education. Dr. Ives has degrees in communication, communication management, and organizational leadership from the University of California at Davis, the University of Southern California, Annenberg School of Communication, and the University of Phoenix-Online, respectively.

\section{REFERENCES}

1. Digest of Education Statistics. Degree-granting institutions, by control and type of institution: 1949-50 to 200-03. Washington, D.C.: National Center for Education Statistics, 2003. Retrieved July 7, 2005, http://nces.ed.gov/programs/digest/d03/tables/dt246.asp.

2. Community College Fact Sheet. Washington, D.C.: American Association of Community Colleges, 2004. Retrieved July 9, 2005, from http://www.aacc.nche.edu/Content/NavigationMenu/About CommunityColleges/Fast Facts1/Fast Facts.htm.

3. O'Rourke, T. Graduate and continuing education for community college leaders. ERIC Digest (ERIC Document \#ED409929), Fall 1996. Retrieved July 10, 2005, from http://www.ericdigests.org /1998-1/graduate.htm.

4. Community college leadership congress focuses on leading the entrepreneurship revolution in America. Washington, D.C.: Association of Community College Trustees, October 13, 2004. Retrieved July 10, 2005, from http://www.acct.org/Template1.asp?bid=864.

5. State funding for community colleges: A 50-state survey. Denver, CO: Center for Community College Policy and Education Commission of the States, 2000. http://www.communitycollegepolicy.org /pdf/CC\%20Finance\%20Survey.pdf.

6. Boggs, G. R. Community colleges in a perfect storm. Change: November-December 2004. Retrieved July 10, 2005, from http://www.findarticles.com/p/articles/mi m1254/is 6 36/ai n9525164. 
7. Ast, J. V. Community college faculty: Making the paradigm shift. Journal of Research \& Practice 23(6): 559-581, September, 1999.

8. Zinser, R. W. Evaluation of a community college technical program by a local industry. Journal of Industrial Teacher Education 40(2): 1-12, Winter 2003. Retrieved July 8, 2005, from http://scholar.lib.vt.edu/ejournals/JITE/v40n2/zinser.html.

9. McClenney, K. M. Redefining quality in community colleges: Focusing on good educational practices. Change: November-December 2004. Retrieved July 10, 2005, from http://www.findarticles.com/p/articles/mi_m1254/is_6_36/ai_n9525166.

10. Kastinas, S. G. Preparing leaders for diverse institutional settings. New Directions for Community Colleges 95: 93-98, 1996.

11. Adelman, C. Moving into town-and moving on: The community college in the lives of traditionalage students. Washington, D.C.: U.S. Department of Education, February 2005. Retrieved July 9, 2005, from http://www.ed.gov/rschstat/research/pubs/comcollege/index.html.

12. Ryan, K. Community colleges beat for-profits on price. Crain's Chicago Business 28(5): 1, January 31, 2005.

13. Collison, M. N. Colleges face competition from for-profits. Community College Week 10(25): 16-19, July 13, 1998.

14. Pope, J. Colleges resist for-profit schools; Plan would make big chains eligible for federal funds. Washington Post, May 8, 2005, A.10. http://www.washingtonpost.com/.

15. Waits, T. and L. Lewis. Distance education at degree-granting post-secondary institutions: 20002001. NCES Publication No. 2003-017. Washington, D.C.: National Center for Educational Statistics, July 2003. Retrieved July 8, 2005, http://nces.ed.gov/pubs2003/2003017.pdf.

16. Digital community colleges and the 'millenials'. T.h.e. Journal: October 2004. Retrieved July 9, 2005, http://www.thejournal.com/articles/17016.

17. Massachusetts Colleges Online Website. About MCO. Retrieved July 10, 2005, from http://www.mco.mass.edu/about.jsp.

18. Perez, S. Project SAIL creates market for specialty courses. Distance Education Report 9(8): 4, April 15, 2005.

19. Gatlin, S. A one-stop shop for web-based learning. Community College Week 17(16): 23.l, March 14, 2005.

20. Graham, M., and J. Patterson. Using cyberspace to remedy the nursing shortage. Community College Week 17(16): 8-13, March 14, 2005.

21. Adams, L. Delivering classes to a digital generation. Community College Week 17(16): 8-10, March 14, 2005.

22. Finkel, E. Going the distance: Online learning programs reach beyond the community college to high schools, employers—and other community colleges. Community College Week 17(20): 6-9, May 9, 2005.

23. Lorenzetti, J. P. Secrets of online success: Lessons from the community college. Distance Education Report 9(11): 3-5, June 1, 2005.

24. DuCharme-Hansen, B. A., and P. A. Dupin-Bryant. Distance education plans: Course planning for online adult learners. TechTrends 49(2): 31-40, March/April 2005.

25. Sloan Consortium. Journal of Asynchronous Learning Networks 8(1): February, 2004. A special issue examining the role of asynchronous learning with a special focus on the characteristics of the community college movement—particularly the access, affordability, and outreach elements.

\section{OTHER RESOURCES}

1. McPhee, S. Hot programs at community colleges. Washington, D.C.: American Association of Community Colleges, 2004. Retrieved July 9, 2005, http://www.aacc.nche.edu/Content /ContentGroups/Research Briefs2/HotProgramsWeb.pdf. 
2. Insight into community colleges. Washington, D.C.: American Association of Community Colleges 2004. Retrieved July 7, 2005, http://www.aacc.nche.edu/Content/NavigationMenu /AboutCommunityColleges/Trends and Statistics/InsightintoCommunityColleges/Insight into Com munity_Colleges.htm.

3. Historical timeline of public education in the US. Oakland, CA: Applied Research Center, 2005. Retrieved July 7, 2005, http://www.arc.org/content/view/100/29/.

4. Dee, J. R. Turnover intent in an urban community college: Strategies for faculty retention. Community College Journal of Research \& Practice 28(7): 593-608, August 2004.

5. Finkel, E. Going the distance. Community College Week 17(20): 6-9, May 9, 2005.

6. Zeiss, T. A new wake-up call for community colleges. Leadership Abstracts (League for Innovation in the Community College) 17(9): September 2004. Retrieved July 9, 2005, http://www.league.org /publication/abstracts/leadership/labs0409.htm.

7. Community college facts at a glance. Washington, D.C.: Office of Vocational and Adult Education, U.S. Department of Education, 2001. Retrieved July 7, 2005. http://www.ed.gov/about/offices/list lovae/pi/cclo/ccfacts.html.

8. Philippidis, A. Peekskill center's a model for community college. Fairfield County Business JournalWestchester County Business Journal 44(24): s24, June 13, 2005. 